\title{
UNDERSTANDING AUSTRALIA'S HuMAN RIGHTS OBLIGATIONS IN RELATION TO TRANSSEXUALS: PRIVACY AND MARRIAGE IN THE AUSTRALIAN CONTEXT
}

\author{
FIONA DAVID AND JAKE BLIGHT*
}

[This article examines recent European jurisprudence on the rights of transsexuals to privacy and marriage. The authors argue that Australia's obligations under the ICCPR should be understood in light of this jurisprudence. On this basis, Australia is obliged to ensure that its authorities: (a) legally recognise the changed gender of post-operative transsexuals; and (b) permit the marriage of post-operative transsexuals to persons of the opposite gender to their re-assigned gender. The authors note the continuing uncertainty around the extension of these rights to transsexuals who have not had 'surgery' but argue in favour of extending ICCPR rights in this way. The authors also consider the legal situation regarding privacy and marriage for transsexuals in Australia. Like the international jurisprudence, Australian laws have not dealt with the situation of transsexuals who have not had surgery. The authors argue that legal distinctions based on the surgical model are more about providing certainty than they are about ensuring the rights and dignity of the people affected. Given Australia's human rights obligations, it would be more appropriate for consideration to be given to the full range of social and cultural factors that affect whether a person is considered to be a man or a woman.]

\footnotetext{
" Fiona David and Jake Blight are both Canberra based lawyers.
} 


\section{INTRODUCTION}

As a party to the International Covenant on Civil and Political Rights (ICCPR), Australia has agreed to respect and to ensure to all individuals within its territory and jurisdiction, the rights recognised in that Convention, without distinction of any kind. ${ }^{1}$ People who identify as transsexual or transgender ${ }^{2}$ are entitled to enjoy these rights, along with other members of society.

Like any law, the obligations in the ICCPR are open to interpretation. Many of the articles in the ICCPR are in similar, if not identical terms to the obligations in the European Convention for the Protection of Human Rights and Fundamental Freedoms (European Convention on Human Rights). Accordingly, developments in the European jurisprudence are relevant to understanding the obligations in the ICCPR. $^{3}$

Recently, there have been significant developments in the European jurisprudence regarding the right of transsexuals to private life and to marry. In this paper, we will examine this jurisprudence and consider its relevance for Australia. We will note that while this jurisprudence is a significant step forward, we hope that courts will continue to keep this issue under review. To date, the jurisprudence has focused on the legal rights of post-operative transsexuals. The situation of transsexuals who have not had surgery is yet to be considered.

In the Australian context, we will look at privacy and State and Territory laws regarding birth certificates. We also consider the law relating to marriage in Australia in light of a recent Full Federal Court decision.

\section{The ICCPR in AUStralia}

The ICCPR came into effect generally in 1976 and for Australia in 1980. In some countries, the ICCPR has been directly incorporated into domestic law. As a result, the domestic courts in those countries can adjudicate issues such as whether a particular right has been breached. This is not the case in Australia.

\footnotetext{
1 Article 2(1), International Covenant on Civil and Political Rights, 1980 ATS 23. The ICCPR entered into force generally (except Article 41) on 23 March 1976, and for Australia (except for Article 41) on 13 November 1980. Article 41 (Inter-State Communications before the Human Rights Committee) came into force generally on 28 March 1979, and for Australia on 28 January 1993.

${ }^{2}$ In this article, the term 'transsexual' is used as a convenient shorthand to describe people who strongly identify themselves as belonging to the gender opposite to that which they were assigned at birth and who express a consistent desire to live in their chosen gender. The legal status of individuals who identify as belonging to a third gender or no gender is beyond the scope of this article.

${ }^{3}$ Dr Manfred Nowak, UN Covenant on Civil and Political Rights, CCPR Commentary (2000) XXIII.
} 
In Australia, treaties do not form part of the domestic law unless and until they are incorporated by statute. ${ }^{4}$ The ICCPR is annexed to the Human Rights and Equal Opportunity Commission Act 1994 (Cth). The Human Rights and Equal Opportunity Commission (HREOC) can inquire into any Commonwealth act or practice that may be inconsistent with or contrary to an ICCPR right. HREOC can report on its findings to the Attorney General, and these reports must be tabled in Parliament. However, HREOC is not a court and its findings do not have the status of judicial determinations. As the ICCPR is not directly incorporated into Australian law (for example, as a bill of rights), it is not possible for Australian courts to adjudicate breaches of ICCPR rights.

Australia is a party to the First Optional Protocol to the ICCPR. ${ }^{5}$ This gives individuals who consider their rights have been breached by Australian authorities the ability to complain to the UN Human Rights Committee about their treatment. The Human Rights Committee considers these complaints ('communications') and then expresses its views on the issue at hand. These views provide useful guidance on the content of ICCPR rights. For example, in 1994, the Human Rights Committee expressed the view that Tasmania's laws criminalising sodomy breached the right to privacy. That year, the Federal Government enacted the Human Rights (Sexual Conduct) Act 1994, effectively preventing State Governments from prosecuting sodomy offences.

To date, the Human Rights Committee has not considered the rights of people who identify as transsexual or transgender. As a result, there is no Human Rights Committee jurisprudence on this issue.

\section{A How do we interpret the ICCPR obligations?}

The ICCPR is subject to the rules of interpretation in the Vienna Convention on the Law of Treaties. ${ }^{6}$ Article 31 of the Vienna Convention states that treaties:

...shall be interpreted in good faith in accordance with the ordinary meaning to be given to the terms of the treaty in their context and in the light of its object and purpose.

The context includes the preamble and the annexes to the treaty.

Clearly, the starting point for interpreting the ICCPR is the text of the treaty itself. Article 31 of the Vienna Convention provides that the words of the treaty are to be

\footnotetext{
${ }^{4}$ See for example, Mason CJ and Deane J in Minister for Immigration and Ethnic Affairs $v$ Teoh (1995) 183 CLR 273.

51991 ATS 39. The First Optional Protocol entered into force generally on 23 March 1976, and for Australia on 25 December 1991.

${ }^{6} 1974$ ATS 2. The Vienna Convention on the Law of Treaties entered into force generally and for Australia on 27 January 1980.
} 
given their ordinary meaning. The ordinary meaning of terms must not be determined in the abstract but in light of the object and purpose of the ICCPR. ${ }^{7}$

It is not always easy to determine the "ordinary meaning" of terms in the ICCPR. Words like 'privacy' and 'marriage' have many different meanings, depending on the time and place of usage. On one view, the "ordinary meaning" of a term is its meaning at the time the ICCPR was negotiated. However, this view is inconsistent with the requirement in the Vienna Convention on the Law of Treaties that meaning be determined in light of the treaties object and purpose. The ICCPR exists to protect human rights and our understanding of human rights is not static. There are many examples of 'rights' that were once considered radical and that are now mainstream. This suggests that, at least in the context of the ICCPR, the ordinary meaning of key terms should be derived from their contemporary usage.

Leading commentators support the view that it is legitimate to consider how key terms are understood in similar human rights conventions to understand the "ordinary meaning" of key terms. ${ }^{8}$ Many of the obligations in the ICCPR are based on the words of the European Convention on Human Rights. The ICCPR and the European Convention on Human Rights treaties share a similar object and purpose. In our view, the European Convention on Human Rights provides a useful guide to the contemporary usage of key terms in the ICCPR.

\section{RECENT EUROPEAN JURISPRUDENCE ON THE RIGHTS OF TRANSSEXUALS}

Unlike the Human Rights Committee, the European Court of Human Rights (the European Court) has considered the human rights of transsexuals in a number of cases. ${ }^{9}$ A review of these cases reflects a changing understanding of the issues, and an emerging consensus in the literature about the medical and social issues surrounding transsexualism.

Cases before the European Court have raised a number of issues, including whether transsexuals have a right to have their new identity recognised by governments, and to marry a person of the opposite gender to their chosen gender.

\section{A Privacy and marriage in the European Convention on Human Rights}

Article 8(1) of the European Convention on Human Rights provides that:

\footnotetext{
7 Sir Robert Jennings QC and Sir Arthur Watts QC, Oppenheim's International Law (9 $9^{\text {th }}$ ed, 1993) 12721273.

${ }^{8}$ Nowak, above n 3, XXIII

${ }^{9}$ See Van Oosterwijck v Belgium (1980) 3 EHRR 557, Rees v UK (1986) 9 EHRR 56; Cossey v UK (1990) 13 EHRR 622; B v France (1992) 16 EHRR 1; Sheffield v Horsham v UK (1998) 27 EHRR 163.
} 
Everyone has the right to respect for his private and family life, his home and his correspondence.

Article 12 provides that:

Men and women of marriageable age have the right to marry and to found a family, according to the national laws governing the exercise of this right.

The first case to consider the rights of transsexuals to privacy and marriage was Rees $v$ UK. ${ }^{10}$ In that case, the European Court considered the social and legal situation of the applicant, Mr Rees, a female to male transsexual who had undergone hormone therapy and a bilateral mastectomy. The Court noted that while transsexualism was not new, 'its features have been identified and examined only recently'. ${ }^{11}$ The Court noted that while transsexuals who have 'been operated upon' form a fairly well defined and identifiable group, there was a lack of consensus among Member States about how the law should respond to transsexualism. ${ }^{12}$ Accordingly, the Court considered that legal recognition of transsexuals is an area where State parties enjoy a wide margin of appreciation. ${ }^{13}$ The Court held that the UK had not violated Mr Rees' right to privacy by refusing to issue him with birth documentation to reflect his change in gender. The Court considered that 'for the time being', it was for the UK to determine how best to respond to the needs of transsexuals. Nonetheless, the Court noted the seriousness of the issues facing transsexuals and stated that this issue should be kept under review, particularly having regard to scientific and societal developments. ${ }^{14}$

In Rees, the Court also considered the argument that the applicant's right to marry had been breached, as the applicant (who was living as a man) could not marry a woman. The Court stated that the right to marry in the European Convention on Human Rights referred to a traditional marriage between persons of the opposite sex. Also, Article 12 provides that the exercise of this right must be subject to national laws. As the Court did not consider that the UK laws prevented the applicant marrying a person of the opposite sex (presumably another man), there was no violation of Article $12 .{ }^{15}$

The Rees case was applied in Cossey $v U K$ in 1990 and again in Sheffield and Horsham $v U K$ in 1998. In these cases, the Court referred to a lack of noteworthy scientific developments in the area of transsexualism, and continuing uncertainty as to the essential nature of transsexualism. ${ }^{16}$

\footnotetext{
${ }^{10}$ (1986) 9 EHRR 56. The Van Oosterwijck case in 1980 raised similar issues but the claim was found to be inadmissible, for non-exhaustion of domestic remedies.

${ }^{11}$ Rees v UK (1986) 9 EHRR 56, 64.

${ }^{12}$ Ibid 64-65.

${ }^{13}$ Ibid 67.

${ }^{14}$ Ibid 67.

15 Ibid 68

${ }^{16}$ Cossey v UK (1990) 13 EHRR 622, 641. Sheffield and Horsham v UK (1998) 27 EHRR 163,192.
} 


\section{B The Goodwin case}

Rees remained the leading case on the issues of privacy, marriage and transsexualism until 2002. In that year, the European Court revisited the issues in its landmark decision, Christine Goodwin v $U K{ }^{17}$ The applicant, a male to female transsexual, asked the European Court to consider two key issues:

- whether the UK had breached its obligation to respect the applicant's 'private life' by refusing to legally recognise her gender re-assignment (Article 8 of the European Convention on Human Rights); and

- whether the UK had violated its obligation to ensure the right of men and women of marriageable age to marry (Article 12 of the European Convention on Human Rights).

The Court noted that it had considered these issues on several previous occasions. However, the Court noted that the Convention exists to protect human rights. Accordingly, the Court was willing to look at changing conditions within the UK and the EU generally and respond to any 'evolving convergence as to the standards to be achieved'. ${ }^{18}$

\section{Right to Privacy}

The Court noted that it had on several occasions signalled its consciousness of the serious problems facing transsexuals. In Cossey and Sheffield, the Court had stressed the importance of keeping this area of the law under review. Accordingly, the Court decided that it would look at the issue of transsexuals and privacy again in the light of 'present-day conditions'. 19

The Court noted the disjuncture between the applicant's personal and legal situation. The applicant had undergone re-assignment surgery and lived as a female, yet she remained 'male' for all legal purposes. The Court also noted that the Government had put some special procedures in place for her. However, these special procedures drew attention to her status as a transsexual. The Court noted the stress and alienation caused by the disjuncture between her personal and legal situation. The Court noted that this conflict may cause feelings of vulnerability, humiliation and anxiety. The Court noted that Ms Goodwin's surgery was carried out and funded by the national health service of the UK. ${ }^{20}$

With regard to medical and scientific considerations, the Court noted that there are still no conclusive findings about the cause of transsexualism and whether it is psychological or physiological. However, the Court thought it was more significant that transsexualism is widely recognised internationally and treatment is available.

\footnotetext{
17 (2002) 35 EHRR 18. See also I v The United Kingdom (2003) 36 EHRR 53, which was handed down on the same day as the Goodwin case (11 July 2002).

18 Goodwin v UK (2002) 35 EHRR 18, 471-472.

19 Ibid 472.

20 Ibid 472-473.
} 
The Court considered the issue of whether there is any European or international consensus about legal recognition following gender re-assignment and noted that:

In Australia and New Zealand, it appears that the courts are moving away from the biological birth view of sex (as set out in the United Kingdom case of Corbett $v$ Corbett) and taking the view that sex, in the context of a transsexual wishing to marry, should depend on the multitude of factors to be assessed at the time of marriage. ${ }^{21}$

The Court noted an international trend in favour of increased social acceptance of transsexuals and of legal recognition of the new gender identity of post-operative transsexuals. $^{22}$

The Court contrasted the seriousness of the on-going consequences for the applicant, with the limited impact that changing the birth register laws would have on the UK authorities. Noting that legal recognition of gender change may have important repercussions in a number of areas such as family law and employment, the Court considered that:

... society may reasonably be expected to tolerate a certain inconvenience to enable individuals to live in dignity and worth in accordance with the sexual identity chosen by them at great personal cost. ${ }^{23}$

The Court noted that the very essence of the Convention is respect for human dignity and human freedom. The Court considered that:

In the twenty first century, the right of transsexuals to personal development and to physical and moral security in the full sense enjoyed by others in society cannot be regarded as a matter of controversy requiring the lapse of time to cast clearer light on the issues involved. In short, the unsatisfactory situation in which post-operative transsexuals live in an intermediate zone as not quite one gender or the other is no longer sustainable. $^{24}$

The Court held that the UK could no longer rely on its margin of appreciation to justify refusing to recognise the applicant's gender reassignment. The UK had failed to respect her right to private life, in breach of Article 8 of the European Convention on Human Rights. ${ }^{25}$

\footnotetext{
21 Ibid 475.

${ }^{22}$ Ibid 474-475.

23 Ibid 477.

24 Ibid 476

25 Ibid 477-478.
} 


\section{The right to marry}

The Court went on to consider whether Ms Goodwin had been denied the right to marry. The Court noted the line of authorities, including Rees, which held that denying a transsexual the ability to marry a person of the opposite sex to their chosen sex was not a breach of the right to marry. Reviewing the situation in 2002, the Court observed that the right to marry is not dependent on any ability to conceive children. Also, getting married gives rise to social, personal and legal consequences. The Court noted major changes in the institution of marriage since the adoption of the Convention, as well as the dramatic changes as a result of science and technology in the field of transsexuality. ${ }^{26}$

The Court rejected the UK's argument that Ms Goodwin was not prevented from getting married, as she could marry a person of the opposite sex to her birth sex. The Court said this argument was 'artificial'. The Court noted that:

The applicant in this case lives as a woman, is in a relationship to a man and would only wish to marry a man. She has no possibility of doing so. In the Court's view, she may therefore claim that the very essence of her right to marry has been infringed. ${ }^{27}$

The Court noted that fewer countries allow transsexuals to marry than recognise their assigned gender. However, this does not mean that the question of whether transsexuals should be permitted to marry should be left to States as being within their margin of appreciation:

This would be tantamount to finding that the range of options open to a Contracting State includes an effective bar on any exercise of the right to marry. The margin of appreciation cannot extend so far. ${ }^{28}$

The Court considered that it was for States to determine the conditions that have to be met for the law to recognise that gender re-assignment has taken place, and the formalities that surround marriage. However, it is not open to States to bar transsexuals from enjoying the right to marry under any circumstances. ${ }^{29}$

\section{$3 \quad$ Cases since Goodwin}

In 2003, the European Court unanimously reaffirmed its reasoning in the Goodwin case in Van Kuck v Germany. ${ }^{30}$ While there was dissent on the ultimate findings in the Van Kuck case, all judges of the European Court referred to the Goodwin case as the leading authority on transsexuals and the rights to privacy and marriage.

\footnotetext{
${ }^{26}$ Ibid 479.

${ }^{27}$ Ibid 480 .

28 Ibid 480 .

29 Ibid 480-481.

30 (2003) 37 EHRR 51.
} 


\section{What are the implications for Australia?}

\section{Privacy}

Article 8(1) of the European Convention on Human Rights provides that:

Everyone has the right to respect for his private... life.

Article 17(1) of the ICCPR provides that:

No one shall be subjected to arbitrary or unlawful interference with his privacy...

Despite some differences in wording, the two obligations are basically the same. ${ }^{31}$ Both are based on the liberal concepts of individual autonomy and respect for the individual.

Under the European Convention on Human Rights, the question of whether an interference with privacy is justifiable depends on whether an appropriate balance has been struck between the interests of the individual on the one hand, and the interests of the state on the other.

In the ICCPR, the balancing act is found in the prohibition of 'arbitrary' interference. Arbitrariness involves elements of injustice, unpredictability and unreasonableness. As the Human Rights Committee has noted:

The introduction of the concept of arbitrariness is intended to guarantee that even interference provided for by law should be in accordance with the provisions, aims and objectives of the Covenant and should be, in any event, reasonable in the particular circumstances. ${ }^{32}$

The question of whether an interference with privacy is justifiable requires a balancing of the circumstances, bearing in mind the principle of proportionality. ${ }^{33}$

\section{Marriage}

Article 12 of the European Convention on Human Rights provides that:

Men and women of marriageable age have the right to marry and to found a family, according to the national laws governing the exercise of this right.

Article 23(2) of the ICCPR provides that:

\footnotetext{
${ }^{31}$ Nowak, above n 3, 294.

32 Human Rights Committee, General Comment No. 16: The Right to Respect of Privacy, Family, Home and Correspondence, and Protection of Honour and Reputation (Article 17), 8 April 1988.

${ }^{33}$ Nowak, above n 3, 293.
} 
The right of men and women of marriageable age to marry and to found a family shall be recognised.

Again, the obligation in the ICCPR corresponds largely to Article 12 of the European Convention on Human Rights. ${ }^{34}$ However, Article 23(2) of the ICCPR does not refer to marriage 'according to national law'. According to Nowak, this suggests that any restrictions on the right to marry should be interpreted narrowly. Discriminatory prohibitions on marriage would represent a violation of Article 23(2) in conjunction with Article 2(1). ${ }^{35}$

If Australia's obligations under the ICCPR are understood in light of the European jurisprudence, then Australia is obliged to ensure that its authorities:

- legally recognise the changed gender of post-operative transsexuals; and

- $\quad$ permit the marriage of post-operative transsexuals to persons of the opposite gender to their re-assigned gender.

These obligations would extend to all branches of government (executive, legislative and judicial), and at all levels - national, regional and local. ${ }^{36}$

It is not clear whether these rights extend to transsexuals who have not undergone surgical procedures. However, there are strong arguments in favour of extending the ICCPR rights in this way. There will be many cases where surgery has little to do with whether a person is socially recognised as a man or a woman. It is consistent with the goal of protecting human dignity to consider the social and cultural factors that go towards recognising a person as a man or a woman, rather than only what surgery an individual may or may not have had.

\section{The Current Situation in Australia}

\section{A Privacy in Australia}

There is no general right to privacy in Australia. The Privacy Act 1988 (Cth) provides some protection in relation to the collection, storage, use and disclosure of personal information by Commonwealth agencies and some private sector bodies. However, the protections contained in the Privacy Act are by no means equivalent to the right to privacy in the ICCPR. Nevertheless, as discussed below, State and Territory laws in Australia go a significant way towards protecting the kind of

\footnotetext{
34 Ibid 407.

35 Ibid 410.

${ }^{36}$ Human Rights Committee, General Comment No. 31, Nature of the General Legal Obligation Imposed on States Parties to the Covenant, CCPR/C/21/Rev.1/Add.13, 26 May 2004.
} 
'privacy' discussed in the Goodwin case. ${ }^{37}$ This is because those State and Territory laws allow many transsexuals to change the sex listed on their birth certificate. As a practical matter, most other documents can be amended once an individual's birth certificate has been changed. This means that those transsexuals who are able to change their birth certificate are given the kind of 'document privacy' at issue in the Goodwin case.

\section{Ability to change birth certificate}

The State and Territory legislation regulating the ability of a transsexual person to change the sex noted on their birth certificate varies between jurisdictions. But all jurisdictions currently require some kind of surgical intervention before an individual's birth certificate can be changed.

\section{Surgical test}

The Northern Territory, the Australian Capital Territory, New South Wales, Queensland, Tasmania and Victoria allow transsexuals to change the sex on their birth certificate through an administrative process. These jurisdictions require that the transsexual person have had surgery involving the alteration of their reproductive organs that was carried out for the purpose of assisting the person to be considered a member of the opposite sex. ${ }^{38}$ Notably, the use of the words 'to be considered' rather then 'to consider themselves' suggests that the considering is done by a person other than the transsexual themselves.

In South Australia and Western Australia the process is more complex and the medical or surgical intervention must have 'altered the genitals and other gender characteristics...so that the person will be identified as a person of the opposite sex' ${ }^{39}$ Again, the 'identifying' is carried out by a person other than the transsexual.

For male to female transsexuals who undergo surgery any of the usual surgical procedures (castration, removal of penis and/or creation of vagina) would seem to meet the surgical test of any of the jurisdictions because the surgery involves the reproductive organs and the genitals. It is likely that any of these surgeries would also 'assist' a person to 'consider' that the individual who has undergone the surgery is a woman. ${ }^{40}$ Although we note that it is not as clear whether, particularly in

\footnotetext{
37 Note that anti-discrimination legislation in Australia also acts to protect transsexual persons in many situations. However, such legislation is not directly relevant to the changing of birth certificates or to marriage which are the focus of this article. A general examination of transsexuals and antidiscrimination legislation is beyond the scope of this article.

${ }^{38}$ See Part 4A of the Births, Deaths and Marriages Registration Act 1996 (NT), Part 4 of the Births, Deaths and Marriages Registration Act 1997 (ACT), Part 5A of the Births, Deaths and Marriages Registration Act 1995 (NSW), Part 4 of the Births, Deaths and Marriages Registration Act 2003 (QLD) Part 4A of the Births, Deaths and Marriages Registration Act 1999 (Tas) and Part 4A of the Births, Deaths and Marriages Registration Act 1996 (Vic).

39 See the Sexual Reassignment Act 1988 (SA) and the Gender Reassignment Act 2000 (WA).

40 This of course begs the question of why the 'assisting' and 'considering' have to be done in such an intimate manner. Our perceptions of most people's gender are formed when we meet them with their
} 
SA and WA, castration alone would be sufficient to allow a person to 'identify' (as opposed to assist to consider) a person as female.

The situation is much more problematic for female to male transsexuals. Female to male transsexuals will often have a mastectomy and possibly a hysterectomy. However, other surgical procedures are uncommon and in particular phalloplasty (the creation of a penis) is complex, expensive and has risks of complications and failure. For these reasons such surgery was considered unnecessary by the Family Court of Australia in Re Kevin and Another ${ }^{41}$ to recognise that 'Kevin' was a man for the purpose of marrying a woman. ${ }^{42}$

A mastectomy alone will generally allow a female to male transsexual whose secondary sex characteristics have been masculinised through the taking of testosterone to be perceived in social situations as a male. However, such surgery would possibly not meet the test of either group of jurisdictions because breasts are not reproductive organs or genitals. For those States and Territories that allow a person to change their birth certificate when they have had 'surgery involving the reproductive organs' a hysterectomy (removal of the uterus and, in some cases, the ovaries) would seem to meet the test. However, as noted above, the test in those jurisdictions is a two-part test and the surgery must also assist the person to be 'considered a member of the opposite sex'. It is difficult to see how, from a practical and social perspective, surgery to remove wholly internal reproductive organs (a hysterectomy) would assist such a person to 'be considered a member of the opposite sex'. ${ }^{43}$ Having said that, an argument can be made that the absence of female reproductive organs assists a person to be considered a member of the opposite sex, although this seems somewhat artificial. ${ }^{44}$ It could also be said that committing to such major surgery evidences a very strong desire to live as a man and that this would assist another person to consider the individual as male. However, at least in the case of female to male transsexuals, it is largely the alteration of secondary sex characteristics (through the administration of testosterone) that allow the individual to be perceived as male, rather than whether they have had a hysterectomy. ${ }^{45}$

clothes on. There seems to be little rational explanation of why the gender of transsexual people is to be considered with their clothes off.

${ }^{41}$ (2001) 165 FLR 404.

${ }^{42}$ Ibid 411, the risks of phalloplasty were noted by Chisholm J. The Attorney-General in that case did not seek to argue that the sex reassignment surgery undertaken by Kevin (mastectomy and hysterectomy) was in any way incomplete or unsuccessful. On appeal in Attorney-General v Kevin and Jennifer (2003) 172 FLR 300, the Full Federal Court also accepted that phalloplasty was not necessary for Kevin to be considered a man for the purpose of the Marriage Act 1961.

${ }^{43}$ Note that ovulation and menstruation is stopped when a person takes high doses of testosterone to masculinise secondary sexual characteristics. On the issue of the ethics of sterilisation see generally, Stephen Whittle, 'Gemeinschaftremden - or how to be shafted by your friends: Sterilisation Requirements and Legal Status Recognition for the Transsexual' in Leslie J Moran and Daniel Monk (eds) Legal Queeries: Lesbian, Gay and Transgender Legal Studies (1999), 43-56.

${ }^{44}$ No doubt many women with no gender issues who have had a hysterectomy would find such an argument either amusing or offensive.

${ }^{45}$ In Re Kevin Chislolm J emphasised the role of secondary sex characteristics and accepted that 'as at the date of his marriage his secondary sexual characteristics were such that he would have been subject 
In WA and SA the legislation specifies that the surgery must alter the genitals. The terms 'genitals' is not defined in either legislation and would therefore have its ordinary meaning. The term 'genitals' is defined in the Macquarie Dictionary as 'reproductive organs, especially the external organs' and in the Oxford English Dictionary as 'the external organ or organs of generation'. If 'genitals' in the WA and SA legislation is interpreted to mean external organs then female to male transsexuals may not be able to change their birth certificates without having surgery which is complex, risky and has a high chance of failure. Indeed, in light of Re Kevin such an interpretation would also produce the anomalous result that some individuals may be considered 'men' for the purpose of marriage but still unable to change their birth certificate. In this regard it is suggested that WA and SA should revisit their legislation in order to better consider the position of female to male transsexuals.

It is also worth noting that in Tasmania a re-issued birth certificate is to include a notation that the person was previously registered as the other sex. ${ }^{46}$ This would seem to defeat the privacy protection that would otherwise be afforded to transsexual people through changing their birth certificate.

State and Territory birth certificate legislation goes a long way towards enabling male to female post-operative transsexuals in Australia to protect their privacy by changing documentation. However, as discussed above, there are some difficulties in applying the surgical test to the circumstances of female to male transsexuals. In particular, the 'genital' test used in WA and SA may result in many female to male transsexuals being unable to change their birth certificates in those States. Furthermore, to apply the legislation to female to male transsexuals in the other jurisdictions it is necessary to accept that wholly internal surgery such as a hysterectomy somehow enables other people to consider the subject of the surgery a man. This highlights the question of whether surgery is really the most appropriate 'test' and what privacy rights are afforded to transsexual individuals who are unable or unwilling to have surgery but nevertheless live in their preferred gender.

\section{Transsexual Marriage in Australia}

The case of Attorney-General v Kevin and Jennifer ${ }^{47}$ stands for the proposition that, for the purpose of the Marriage Act 1961 (Cth), the question whether a person is a 'man' or a 'woman' is to be decided as at the date of their marriage (rather than at the date of their birth). Furthermore, 'man' and 'woman' have their ordinary, current meaning according to Australian usage. The result in this case, in effect,

to ridicule if he had attempted to appear in public dressed as a woman, that he could not have entered a women's toilet...'(165 FLR 404, 412)

${ }^{46}$ Subsection 28D(1) Births, Deaths and Marriages Registration Act 1999 (Tas). Although an extract from a birth certificate can be obtained without the notation (subsection 28D(2)).

47 (2003) 172 FLR 300. 
means that post-operative transsexuals can marry in their re-assigned gender in Australia. This is consistent with the ICCPR obligations discussed above.

Since the decision in Attorney-General $v$ Kevin and Jennifer the Marriage Act has been amended to specify that a marriage means the 'union of a man and a woman to the exclusion of all others, voluntarily entered into for life'. However, the amendment did not seek to define 'man' or 'woman'. This suggests that parliament was not seeking to change the approach taken in Attorney-General $v$ Kevin and Jennifer that those terms have their ordinary meaning. In other words, although the recent amendments may have affected same-sex marriage, the amendments have not affected transsexual marriage. The validity of a marriage involving a transsexual therefore continues to turn on whether the individual concerned is a 'man' or a 'woman' at the time that they marry according to the ordinary meaning of those terms. It seems clear that the terms 'man' and 'woman' include a post operative transsexual living in the relevant gender. ${ }^{48}$ A more complex issue is whether the term 'man' or 'woman' could include a pre-operative transsexual.

\section{A The rights of pre-operative transsexuals ${ }^{49}$}

The case law in Australia suggests a reluctance to recognise pre-operative transsexuals as belonging to their self-identified gender. ${ }^{50}$

There are of course a range of reasons why individuals who regard themselves as transsexual may not undergo surgery. These include the cost of the surgery, the health risks involved and, particularly in the case of female to male transsexuals, questions as to whether wholly internal surgery will in any way assist them to live in their preferred gender.

In the case of $R v$ Harris and McGuiness ${ }^{51}$ both Harris and McGuiness were charged with being male persons attempting to procure the commission of indecent acts. The main issue was whether they were 'male persons'. The evidence was that Harris was a post-operative male to female transsexual and McGuiness was a preoperative male to female transsexual. Matthews J expressed 'the greatest sympathy

\footnotetext{
${ }^{48}$ It is not clear exactly what surgery a particular individual would need to have to be classified as 'postoperative' but it is likely that a court would be influenced by the test used for changing birth certificates. However, as discussed above the test varies between jurisdictions and it is arguable that if Kevin has been born in SA or WA he may not have been able to change his birth certificate because he had not had 'genital' surgery.

49 For the purpose of this article the term 'pre-operative' is used to identify the class of transsexual persons who would otherwise be regarded as belonging to their preferred gender but have not had surgery involving the reproductive organs for whatever reason.

${ }^{50}$ See for example $R v$ Harris and McGuiness (1988) 35 A Crim R 146; Secretary, Department of Social Security $v$ SRA 118 ALR 474; E v Minister for Health and Faminly Services, Human Rights and Equal Opportunity Commission, 8 October 1988, No H97/219; SRDD v Secretary, Department of Family and Community Services [1999] AAT 626, AAT 25 August 1999; VZG v Secretary, Department of Family and Community Services [1999] AATA 298 AAT, 7 May 1999.

51 (1988) 35 A Crim R 146.
} 
for Ms McGuiness and for others in her predicament' but considered surgery to be necessary because a test not reliant on surgery would:

... create enormous difficulties of proof, and would be vulnerable to abuse by people who were not true transsexuals at all. To this extent it could lead to a trivialisation of the difficulties genuinely faced by people with gender identification disharmony. ${ }^{52}$

This statement may be read as implying that 'true transsexuals' are those who undergo surgery while those who do not must somehow not have gender identification disharmony. However, there is nothing on the facts of that case to suggest that the disharmony felt by McGuiness was any lesser than that experienced by Harris. Indeed, it might be that Mc Guinness' disharmony was greater because of the presence rather than the absence of her male genitalia. Further, the 'difficulties' faced by pre-operative transsexuals cannot be ignored. This is highlighted by the particular difficulties faced by transsexual inmates. ${ }^{53}$

The judgment in McGuiness and other cases involving pre-operative transsexuals suggests a focus on ensuring a test that can be relatively easily applied by the courts to categorise people rather than on what steps the law can take to protect the dignity and rights of individuals. However, given the range of so-called 'sexual reassignment' procedures ${ }^{54}$ and the varying standards used to assess what type of surgery is required to change, for example a birth certificate, the test of 'surgery' is not altogether satisfactory.

Arguably, the recent decision in Attorney-General $v$ Kevin and Jennifer has gone someway towards moving beyond a strictly surgical test and towards a test that takes account of social, cultural and a broader range of biological factors including 'brain sex'. ${ }^{55}$ Such an approach may allow a pre-operative transsexual to be recognised by the law as belonging to their preferred gender. The judge in the first instance was careful to avoid making a ruling on pre-operative transsexuals ${ }^{56}$ and the full Federal Court on appeal likewise gave no answer to the question of whether

\footnotetext{
${ }^{52}$ Ibid 181-182. Also see Secretary, Department of Social Security v SRA 118 ALR 474 where the Federal Court rejected a claim that a pre-operative male to female was a woman.

${ }^{53}$ See generally Jake Blight, Transgender Inmates, Trends and Issues in Criminal justice No. 168, Australian Institute of Criminology (2000); Inquiry into the Death of Catherine Moore, Coroner J Abernethy, 21 July 1999, NSW State Coroner's Court W308 201/99 JI-D1..

${ }^{54}$ There is no single 'sex re-assignment surgery'. Rather there are a range of procedures available. For example (for male to female): penectomy (removal of penis), orchidectomy (castration), vaginoplasty (creation of vagina), clitoroplasty (creation of clitoris), labioplasty (creation of labia), breast augmentation, scalp advancement and brow position change, orbital rim reduction, cheek augmentation, rhinoplasty, chin and jaw re-sculpting, thyroid cartlidge reduction (reduction of adam's apple), thigh and buttock augmentation. And, (for female to male): bilateral mastectomy, hysterectomy and removal of ovaries, scrotum construction and testicular implants, phalloplasty (creation of penis), metiotoidaplasty (clitoral release), urethroplasty (extension of urethra) and vaginectomy (removal of vagina).

55 See the extensive discussion of the medical evidence including that relating to 'brain sex' in Re Kevin $v$ Attorney-General (2001) 165 FLR 404, 450 -463 and the comment of the Full Federal Court on appeal that in light of the evidence about brain sex it was open to Chisholm $\mathrm{J}$ to find that transsexualism was biologically caused (172 FLR 300, 347-348 and 354-355).

56165 FLR 404, 409.
} 
the courts can logically maintain a distinction between pre-operative and postoperative transsexuals. ${ }^{57}$ Rather, the position taken by the courts seems to be that the question of whether a person is a man or a woman is a question of fact to be decided on the facts of each case.

The facts that led the trial judge to conclude that Kevin was a man at the time of his marriage are summarised at $\mathrm{p} 476$ of the decision as follows:

In the present case, the husband at birth had female chromosomes, gonads and genitals but was a man for the purpose of the law of marriage at the time of his marriage, having regard to all the circumstances and in particular the following:

(a) he had always perceived himself to be a male;

(b) he was perceived by those who knew him to have had male characteristics since he was a young child;

(c) prior to the marriage he went through a full process of sexual reassignment, involving hormone treatment and irreversible surgery, conducted by appropriately qualified medical practitioners;

(d) at the time of the marriage, in appearance, characteristics and behaviour he was perceived as a man, and accepted as a man, by his family, friends and work colleagues;

(e) he was accepted as a man for a variety of social and legal purposes, including name, and admission to an IVF program, and in relation to such events occurring after the marriage, there was evidence that his characteristics at the relevant times were no different from his characteristics at the time of the marriage;

(f ) his marriage as a man was accepted, in full knowledge of his circumstances, by his family, friends and work colleagues.

On appeal the Full Federal court agreed with these reasons. ${ }^{58}$

Notably, of these six factors only one concerns surgery and that refers to both surgery and hormone treatment. This is not to suggest that surgery is an unimportant factor. Rather, that surgery is but one factor and that if a case came before the courts with facts that showed a person met all of the other factors it may be open to the court to conclude that, even in the absence of surgery, they belonged to their self-identified gender.

\footnotetext{
${ }^{57} 172$ FLR $300,365-366$

${ }^{58} \operatorname{Ibid} 365$
} 


\section{CONCLUSION}

If Australia's obligations under the ICCPR are understood in light of the European jurisprudence, then Australia is obliged to ensure that its authorities:

- legally recognise the changed gender of a post-operative transsexuals; and

- permit the marriage of post-operative transsexuals to persons of the opposite gender to their re-assigned gender.

These obligations would extend to all branches of government (executive, legislative and judicial), and at all levels - national, regional and local.

It is not clear whether these rights extend to transsexuals who have not undergone surgical procedures. However, there are strong arguments in favour of extending the ICCPR rights in this way. There will be many cases where surgery has little to do with whether a person is socially recognised as a man or a woman. It is consistent with the goal of protecting human dignity to consider the social and cultural factors that go towards recognising a person as a man or a woman and not only what surgery an individual may or may not have had.

In Australia there is State and Territory legislation that enables many post-operative transsexuals to change the sex noted on their birth certificate. This legislation goes a long way towards protecting the privacy of post-operative male to female transsexuals. However, because of the genital surgery requirement in SA and WA female to male transsexuals in those jurisdictions are not as well protected.

Marriage in Australia must be between a 'man' and a 'woman'. For the purpose of the Marriage Act those terms have their ordinary contemporary meaning. The question of whether a person is a 'man' or a 'woman' is to be assessed at the date of their marriage, not at the date of their birth. The matters that a court can take into account in deciding whether a person is a 'man' or a 'woman' include social, cultural, biological and surgical factors. The leading case on this issue in Australia concerns a post-operative transsexual. However the case leaves it open to future courts to consider whether a pre-operative transsexual may be able to marry in their self-identified gender. 